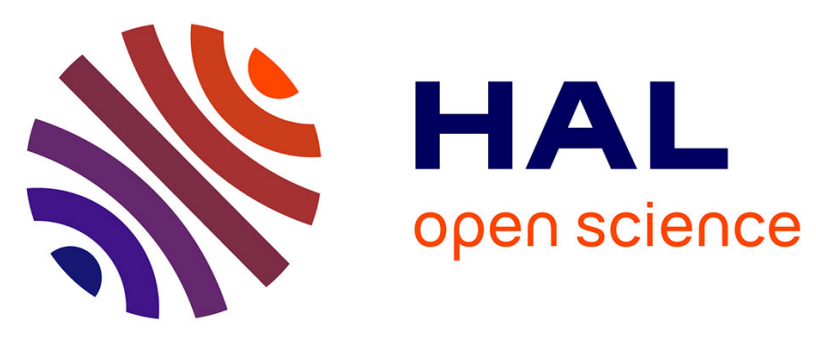

\title{
Tax ubiquitylation and SUMOylation control the dynamic shuttling of Tax and NEMO between Ubc9 nuclear bodies and the centrosome
}

Youmna Kfoury, Niclas Setterblad, Marwan El-Sabban, Alessia Zamborlini, Zeina Dassouki, Hiba El Hajj, Olivier Hermine, Claudine Pique, Hugues de Thé, Ali Saïb, et al.

\section{To cite this version:}

Youmna Kfoury, Niclas Setterblad, Marwan El-Sabban, Alessia Zamborlini, Zeina Dassouki, et al.. Tax ubiquitylation and SUMOylation control the dynamic shuttling of Tax and NEMO between Ubc9 nuclear bodies and the centrosome. 15th International Conference on Human Retroviruses: HTLV and Related Viruses, Jun 2011, Leuven and Gembloux, Belgium. pp.A146, 10.1186/1742-4690-8-S1-A146 . inserm-00663646

\section{HAL Id: inserm-00663646 https://www.hal.inserm.fr/inserm-00663646}

Submitted on 27 Jan 2012

HAL is a multi-disciplinary open access archive for the deposit and dissemination of scientific research documents, whether they are published or not. The documents may come from teaching and research institutions in France or abroad, or from public or private research centers.
L'archive ouverte pluridisciplinaire HAL, est destinée au dépôt et à la diffusion de documents scientifiques de niveau recherche, publiés ou non, émanant des établissements d'enseignement et de recherche français ou étrangers, des laboratoires publics ou privés. 


\title{
Tax ubiquitylation and SUMOylation control the dynamic shuttling of Tax and NEMO between Ubc9 nuclear bodies and the centrosome
}

\author{
Youmna Kfoury ${ }^{1}$, Niclas Setterblad ${ }^{2}$, Marwan El-Sabban ${ }^{3}$, Alessia Zamborlini ${ }^{4}$, Zeina Dassouki ${ }^{1}$, Hiba El Hajj ${ }^{1}$, \\ Olivier Hermine ${ }^{5}$, Claudine Pique ${ }^{6}$, Hugues de Thé ${ }^{4}$, Ali Saïb ${ }^{4}$, Ali Bazarbachi ${ }^{*}$
}

From 15th International Conference on Human Retroviruses: HTLV and Related Viruses

Leuven and Gembloux, Belgium. 5-8 June 2011

The HTLV-I oncoprotein Tax is critical for T cell transformation, acting mainly through NEMO binding and subsequent NF- $\kappa \mathrm{B}$ activation. Tax localizes to Tax nuclear bodies and to the centrosome and is subjected to ubiquitylation and SUMOylation that are both necessary for complete transcriptional activation. By using the photoconvertible fluorophore Dendra-2 coupled with live video confocal microscopy, we show for the first time that the same Tax molecule shuttles among Tax nuclear bodies and between these nuclear bodies and the centrosome depending on its post-translational modifications. Ubiquitylation targets Tax to nuclear bodies to which NEMO is recruited and subsequently SUMOylated. We also demonstrate that Tax nuclear bodies contain the SUMOylation machinery including SUMO and the SUMO conjugating enzyme Ubc9, strongly suggesting that these nuclear bodies represent sites of active SUMOylation. Finally, both ubiquitylation and SUMOylation of Tax control NEMO targeting to the centrosome. Altogether, we are proposing a model where both ubiquitylation and SUMOylation of Tax control the shuttling of Tax and NEMO between the cytoplasmic and nuclear compartments.

\section{Author details \\ 'Department of Internal Medicine, American University of Beirut, Beirut, Lebanon. ${ }^{2}$ Imagery Department of the Institut Universitaire d'Hématologie IFR105, Paris, France. ${ }^{3}$ Department of Human Morphology, American University of Beirut, Beirut, Lebanon. ${ }^{4}$ UMR 7212 CNRS, U944 Inserm, Laboratoire Associé au Comité de Paris de la Lique contre le Cancer, Paris, France. ${ }^{5}$ CNRS UMR 8603 and Department of Hematology, Necker Hospital,}

\footnotetext{
*Correspondence: bazarbac@aub.edu.lb

'Department of Internal Medicine, American University of Beirut, Beirut, Lebanon

Full list of author information is available at the end of the article
}

Paris, France. ${ }^{6}$ INSERM U1016, CNRS UMR 8104, Université Paris Descartes, Institut Cochin, Department of cell Biology and Host-Pathogens Interactions, Paris, France.

Published: 6 June 2011

\section{doi:10.1186/1742-4690-8-S1-A146 \\ Cite this article as: Kfoury et al: Tax ubiquitylation and SUMOylation control the dynamic shuttling of Tax and NEMO between Ubc9 nuclear bodies and the centrosome. Retrovirology 2011 8(Suppl 1):A146.}

Submit your next manuscript to BioMed Central and take full advantage of:

- Convenient online submission

- Thorough peer review

- No space constraints or color figure charges

- Immediate publication on acceptance

- Inclusion in PubMed, CAS, Scopus and Google Scholar

- Research which is freely available for redistribution

Submit your manuscript at www.biomedcentral.com/submit

\section{() Biomed Central}

\section{Biomed Central}

(c) 2011 Kfoury et al; licensee BioMed Central Ltd. This is an open access article distributed under the terms of the Creative Commons Attribution License (http://creativecommons.org/licenses/by/2.0), which permits unrestricted use, distribution, and reproduction in any medium, provided the original work is properly cited. 